\title{
Issues in the Designing of Public Sector Reform
}

\author{
NADEEM UL HAQUE \\ "The commitment to reform cannot long survive, unless government provides \\ adequate pay, recognition for jobs well done, accessible training, and decent working \\ conditions."
}

The Volker Commission (1990).

\section{INTRODUCTION}

"Civil service reform," which has become the nickname for public sector management reform in the parlance of development economics, has only recently and grudgingly been accepted by those who advise on policy in the poor countries. Even then, the approach is somewhat paternalistic in that it emphasises externally-designed rules and processes for management, organisation, audit and accountability. It recognises the role of people in terms of noting that incentives and employment policies matter but only in terms of right-sizing the government and second to the need to spread budgetary resources over the politically chosen level of employment. What it does not accept is that and the drive to manage the public sector better has to be led and implemented by the domestic talent and in that they must have both the incentive and the honour of doing just that.

This paper argues that the main reason that the public sector management has suffered in many of the poor countries is that incentives have been allowed to erode rapidly as public sector employment was viewed politically as a means of providing welfare. This lead to the outflow of many of the better quality people form the civil service and through adverse selection of the decline of work and ethical standards.

Nadeem ul Haque works at the IMF Institute, International Monetary Fund, Washington, D. C., USA. 
Public sector productivity has dwindled as a result while human capital which at first avoided the public sector now started to leave the country. To rebuild the public sector, these countries now have to rely on expatriate human capital in the form of technical assistance.

\section{GOVERNMENT IN A GROWTH MODEL}

First-generation growth literature relied on the traditional two factors-labour and capital—measured in notional natural units and a production function that relied on constant returns to scale [Solow (1965); Cass (1973) and Koopmans (n.d.)]. Growth was, therefore, exogenously determined by the rate at which these factors grew which in turn depended on the growth rate of the population and the rate of time preference which determined domestic consumption-saving decisions and hence capital accumulation. Policy action was unnecessary and most countries in steady state would converge to the same level of incomes and growth.

Empirical studies of growth however, showed that convergence was not taking place as suggested by those models [Lucas (1988) and Romer (1986, 1990)]. Moreover, factor accumulation explained only a part of growth. The large unexplained residual that remained was considered to be due to factors such as technological change and human capital [Dennision (n.d.)]. Over time some of the differences across countries has been shown to be due to variables such as years of schooling as well as other demographic indicators to capture human capital development, and government expenditures which are considered to represent the impact of government provided infrastructure as well as several indicators measuring political, institutional and social development. These investigations have shown that the role of government and policy may be an important variable that could explain why some countries remain poor and others improve their living standards. Consequently, this paper examines the role of government in the growth process.

Following Barro (1990) and Haque and Montiel (1992), government intervention is necessary for the provision of public goods such as the maintenance of law and order, administering legal, regulatory and supervisory systems that facilitate market-functioning, and the development and maintenance of road and communication networks. Presumably, both the quantity and the quality of these public services affects the production process of the private sector and hence eventually affects growth. Thus, for example a safe working environment which prevails when law and order is being efficiently maintained means little loss of working time; a properly regulated and supervised financial market allows for more capital availability because of better financial intermediation; and an efficient and speedy legal system can allow for improved and effective contracting so necessary for market transactions. However, in order to provide these services, the government 
uses available technologies and resources. It raises revenues by means of taxation and purchases inputs from the market the same as the private sector. The efficiency of resource use as well as any competition and eventual utilisation of certain scarce resources among the two competing sectors are likely to have important implications for the growth process. ${ }^{1}$ The relationship between the government wage structure and that prevailing in the private sector can be summarised in the following proposition from Haque and Sahay (1996) and Haque and Aziz (1998).

Proposition 1. On the basis of existing technology, there exists an optimal government wage policy (relative to that prevailing in the private sector) that maximises government output, as well as private sector output. The compression of the government wage structure beyond this optimal policy are associated with welfare losses.

We can model the government as operating under a production technology similar to that of the private sector. Thus the government produces a joint product of public infrastructure as well as the efficient collection of its taxes. It does so using the standard inputs of physical and human capital within the technological constraints of the time. ${ }^{2}$ Both firms and bureaucrats, therefore, develop a cooperative contract in which the potential tax revenue is divided in three parts. One part is kept by the firm another goes to the bureaucrat while the third goes to the government as revenues. The result of all this is that direct tax revenue collections being to fall below potential for what is commonly and euphemistically termed "weakness in tax administration and control". Fiscal pressures build up because of declining revenues, and are dealt with by a combination of the standard approaches (a) reduction in expenditures which include a cut in public sector wages, and (b) increased resort to the inflation tax. In either case, real wages are further eroded reinforcing the process just described: lowered quality of human capital in the public sector, a decline in monitoring quality and public good output reduction leading to an increased proclivity on the part of both bureaucrats and firms for corruption, and therefore a decline in domestic revenues. The cycle is reinforced.

The above discussion can be summarised in the following proposition from Haque and Sahay (1996) which suggests directions for reforming the public sector.

${ }^{1}$ Although the government produces a public good which is a direct input into the production process of the private sector, it cannot, given the public good nature of its service, efficiently price the service or the good it provides. It, therefore, finances this production by means of tax revenue collections both direct and inflation taxation. The collection of direct taxes is another function that the government must attempt to do efficiently if the difficulties associated with the inflation tax are to be avoided.

${ }^{2}$ In order for the story that is developed later, the production function must incorporate different skill or human capital levels and perhaps even allow these levels to be complementary in use (the manager-worker story). 
Proposition 2: Corruption increases and public sector productivity declines with declining wage incentives and when institutional arrangements are weak, i.e., when there is both a low probability of detection and a relatively minor punishment in the event of conviction.

\section{PUBLIC SECTORS IN DEVELOPING COUNTRIES: SOME EMPIRICAL FACTS}

The simple model presented above illustrates the critical role that the quality of governance plays in determining income and growth in an economy. Unfortunately, there is little data available to test this relationship in a regression. Because the public sector has traditionally been viewed merely as a transfer mechanism, there is little systematic evidence available on input utilisation in the government or on the quality of its output. Reliable data on the structure of public sector wages and employment are not available for most developing countries. ${ }^{3}$ The studies that do provide information on some limited aspects of public sector management are only meant to provide a snapshot of the public sector at a point in time. ${ }^{4}$ It is not possible, therefore, to derive from them panel data of sufficient length to allow a formal empirical investigation. ${ }^{5}$ The available evidence on wage, employment and human capital policies in the public sector wages suggests the following stylised facts:

(a) Public Wages Decline in Real Terms Over Time: Evidence from a number of countries suggests that real wage levels for public sector employees have been declining over long periods in many developing countries. ${ }^{6}$ Table 1 presents the trend growth in real wage levels in the general government. Our estimates include all the countries for which data were available and for as many years as the data permitted. The trend regressions indicate that, since the mid-1970s, real wage levels in the general government declined in 19 of the 29 countries. In the remaining five countries which registered positive growth rates, the highest was Ghana at four percent per annum. In transition economies, large-scale liberalisation of prices accompanied by wage controls led to a decline in real wages in the public sector, particularly during the

${ }^{3}$ Snapshots on the basis of sparse and disjointed data series are obtained from some individual efforts which demonstrate the nature of problem. It is surprising that there is no systematic effort to collect more information on this issue which is considered to be at the heart of economic development.

${ }^{4}$ See Lindauer and Nunberg (1994); Chaudhry et al. (1994) and Van Ginneken (1991).

${ }^{5}$ The information that is available is itself affected by public sector inefficiencies. For example, increasing public sector inefficiency leads to the problems of ghost workers that makes it difficult accurately to record public sector employment [see Lindauer and Nunberg (1994)].

${ }^{6}$ For example, as far back as 1983, Gould and Amaro-Reyes noted that in Africa and Latin America, salary levels at middle and low level were at times so low the officials could not even have a balanced diet. 
Table 1

Selected Developing Countries: Trends in Real Wages in General Government (Annual Percent Change)

\begin{tabular}{|c|c|c|}
\hline & Time Period & $\begin{array}{c}\text { Real Wage Trend in General } \\
\text { Government }\end{array}$ \\
\hline Argentina & 1976-89 & -3.1 \\
\hline Armenia & 1992-95 & -45.0 \\
\hline Belarus & 1992-95 & -14.0 \\
\hline Bolivia & 1985-91 & 2.3 \\
\hline Bulgaria & 1989-92 & -17.7 \\
\hline Congo & $1980-83$ & -3.8 \\
\hline Costa Rica & 1974-93 & 1.7 \\
\hline Czechoslovakia & 1989-92 & -11.7 \\
\hline Estonia & 1992-95 & 6.0 \\
\hline Fiji & 1985-93 & -1.7 \\
\hline Gabon & 1985-91 & 3.4 \\
\hline Ghana & 1986-90 & 4.4 \\
\hline Hungary & 1989-92 & -0.8 \\
\hline India & 1979-84 & 3.8 \\
\hline Kenya & 1982-92 & -2.2 \\
\hline Kyrgyz Republic & 1992-95 & -20.0 \\
\hline Latvia & 1992-95 & 7.0 \\
\hline Lithuania & 1992-95 & -10.0 \\
\hline Mauritius & 1974-92 & 1.3 \\
\hline Morocco & 1980-89 & -1.6 \\
\hline Myanmar & 1987-92 & -0.5 \\
\hline Panama & 1973-91 & 0.6 \\
\hline Poland & 1989-92 & -10.3 \\
\hline Romania & 1989-92 & -8.9 \\
\hline Russia & 1992-95 & -11.0 \\
\hline Rwanda & 1985-89 & -2.0 \\
\hline Solomon Islands & 1988-91 & 1.6 \\
\hline Suriname & 1984-86 & -8.3 \\
\hline Ukraine & 1992-95 & -20.0 \\
\hline Average $^{*}$ & & -9.0 \\
\hline
\end{tabular}


initial stages. For the sample as a whole, real wages declined by about 9 percent per annum.

(b) Increase of Non-wage Benefits: The wage declines have been accompanied by an increase in perks and other non-wage benefits that are not only harder to monitor but provided at a higher cost than the value or benefit that the recipient derives. As economists have known since Friedman's argument against school lunches, the provision of non-wage benefits is an inefficient and expensive way of providing compensation: the cost of the government is higher than the benefit received by the civil servant.

(c) Corruption and Maladministration Increases with Declining Real Wages: Over time, the declining real wage in the public sector had two important effects. First, this wage policy results in a sort of dynamic adverse selection as productivity in the public sector declined as the quality of public sector employee declined in response to the wage decline. Second, incentives to rent seeking and corruption are increased as the public sector officials find that their decline in real wages can be made up quite readily by the marketing of public properties such as licenses and controls [see Schleifer and Vishny (1993)]. The declining human capital in the public sector lowers public sector output including the self-policing of the government. ${ }^{7}$ The costs associated with corruption are lowered and expected returns increased as a result [Haque and Sahay (1996)]. Declining public sector output also lowers private sector output and profitability because of the lower level of public good input that is now available. The incentive for firms to cheat the government is, therefore, increased. Additionally the increase in nonwage benefits encourages and weaken morally-correct behaviour as the incentive to maximise hidden non-wage benefits is set in motion. It is not surprising then that the declining real wages in public sector [Weder and van Rijckeghem (1997)] has been found to be correlated with corruption which in turn has been found to be detrimental to growth [Mauro (1995)].

(d) Declines Larger in Poor Countries: The decline in government wage relative to per capita incomes is not uniform across countries. The poorer countries experienced a larger decline during the 1970s. During the 1980s the decline was reversed, but not enough to correct the declining trend over the entire period.

(e) Declining Public-private Wage Differential: Some evidence of trends in the ratio of public to private wage for countries for which data was available is presented in Table 2. Once again we see that this ratio declined for most

${ }^{7}$ An additional plausible assumption that increased education increases the aversion to, or the costs associated with illegal activities world reinforce this phenomenon. 
Table 2

Selected Developing Countries: Trends in the Ratio of Government to Private Sector Average Wages (Annual Percent Change)

\begin{tabular}{lrc}
\hline & Time Period & Trend \\
\hline Bolivia & $1985-91$ & 4.0 \\
Costa Rica & $1974-93$ & -0.8 \\
Fiji & $1985-93$ & -27.0 \\
Ghana & $1986-90$ & -8.0 \\
Kenya & $1982-92$ & -3.0 \\
Mauritius & $1974-92$ & -0.4 \\
Panama & $1973-91$ & 2.0 \\
Peru & $1985-92$ & -25.0 \\
Poland & $1989-92$ & -0.4 \\
Suriname & $1985-92$ & -1.0 \\
Average & & -6.0 \\
\hline
\end{tabular}

Source: National authorities.

countries. $^{8}$ On average, it shows a decline of about 6 percent per annum. Flanagan (1995) finds that full-time employees in the private sector earn considerably more than their counterparts in the state sector in the Czech Republic. $^{9}$

(f) Stabilisation at the Expense of Public-sector Efficiency: Some recent studies on stabilisation programmes suggest that fiscal adjustments often involve a decline in real wages in the public sector. The data show that shortterm stabilisation programmes have a significant negative impact on real wages [Kraay and van Rijckeghem (1995)] while they protect overall wage expenditures of the government [Hewitt and van Rijckeghem (1995)]. ${ }^{10}$ It

${ }^{8}$ Through a fairly comprehensive cross-country study of government wages relative to the private sector. Heller and Tait (1984) showed that during the late 1970s and the early 1980s the ratio of public wages to private wages was lower in developing countries than in industrial countries. This evidence is somewhat surprising since one would expect that in developing countries, on average, the quality of human capital would be higher in the government relative to the underdeveloped private sector [Heller and Tait (1984)].

${ }^{9}$ After controlling for schooling and potential experience, survey results show that workers in new private firms earn 18 percent more than those in current or former state enterprises.

${ }^{10}$ Hewitt and van Rijckeghem (1995) examine the determinants of central government wage expenditures for 99 countries during 1980-1990. They found that heavily indebted countries tend to have lower central government wage expenditures relative to GDP. 
would seem that such programmes protect employment at the cost of real wages.

(g) Wage Compression: Wages at upper levels of public administration have often been reduced by more than those at the at lower levels. Figure 1 illustrates this phenomenon for several countries. With a base year of 1975=100, the figure shows the 1985 wage level at the lowest (solid) and highest (hatched) wage levels in the public sector. Note that with one exception, real wage declines were experienced at both the highest and lowest wage levels in the public sector in this sample. ${ }^{11}$ The numbers at the end of each country's bar group present the ratio of the wage indices given in the figure for each country, expressing the relative 1985 real wage index for those at the lowest end of the wage scale as a multiple of the relative 1985 wage index for those at the highest end, converted to an index number. Since 1975 is the base year, a ratio in excess of 100 indicates an increase in wage compression. The countries are ranked in decreasing order of wage compression during the 1975-85 period. Note that wage compression is observed for all the countries in the sample except Morocco and Benin. ${ }^{12}$

(h) The Political Imperative of Protecting Employment: During this period of compression and decline in real public sector wage levels, the share of the labour force employed in the sector remained relatively constant or may even have increased somewhat. The situation is illustrated in the left-hand portion of Figure 2, which shows the percentage of the population employed in the public sector in a group of developing countries drawn from the previous sample $^{13}$ from 1975 through 1985, a period corresponding to that for which we have relative wage data. This steady share of employment has occurred despite the fall in wages in the public sector relative to other sectors. In more recent years, the right-hand portion of Figure 2 suggests that there may have been actual increases in the share of labour employed in the public sector.

(i) Hierarchical, Unified, Closed and Non-meritocratic Structures: Perhaps because of the paternalistic nature of the state, the civil services in most poor countries tend to be fairly rigid, often prevent entry and reward seniority rather than performance. Public expenditure management is our only measure of bureaucratic performance and it measures only budgetary allocations, without really concerning itself with the service that each budgetary unit is supposed to provide [Premchand (1993)].

${ }^{11}$ See Van Ginnekin (1991); Lindauer and Nunberg (1994); Chaudhry et al. (1994) and Haque and Sahay (1996).

${ }^{12}$ The data show that public sector wages are, in most cases, lower than private sector wages at both grade levels, particularly at the highest grade levels [see Haque and Sahay (1996)].

${ }^{13}$ The number of countries varies across years according to the availability of data. 
Figure 1

Fig. 1. Real Public Sector Wages and Wage Compression: 1975-85.

\begin{tabular}{|c|c|c|c|c|c|c|c|c|}
\hline Zimbabwe & \multicolumn{2}{|c|}{ Ethiopia } & Nigeria & Kenya & Sudan & Tunisic & & \\
\hline Sierra Leone & \multicolumn{2}{|c|}{ Tanzania } & CAR & \multicolumn{2}{|l|}{ Gambia } & Togo & \multicolumn{2}{|l|}{ Morocco } \\
\hline Benin & & & & & & & & \\
\hline 278 & 193 & 174 & 171 & 163 & 132 & 127 & 122 & \\
\hline 115 & 98 & 87 & & & & & & \\
\hline 20 & 40 & 60 & 80 & 100 & 120 & 140 & 160 & 180 \\
\hline
\end{tabular}

Figure 2

Fig. 2. Employment Indicators in Some Developing Countries.

\begin{tabular}{llllllllll}
\multicolumn{7}{l}{ Percentage } & \multicolumn{7}{c}{ Year } \\
0 & 0.5 & 1 & 1.5 & 2 & 2.5 & 3 & 3.5 & 4 & \\
75 & 76 & 77 & 78 & 79 & 80 & 81 & 82 & 83 & \\
84 & 85 & 86 & 87 & 88 & 89 & 90 & 91 & 92 & 93
\end{tabular}


(j) CSR Efforts by IFI's Less than Successful: The conclusion of a recent survey of the most recent decade of civil service reform in SSA is that the first-generation reform of the quantitative adjustments has been completed to the detriment of the quality of the civil service. ${ }^{14}$ All the reviews of the almost two decades of reform suggest that the preoccupation of civil service reform has really been the containment of fiscal pressures and that deeper management issues of ensuring a more responsive public administration based on quality performance clearly remain. What is most interesting is that given the concentration of the reform on the broad expenditure-cutting macro requirement, there was not even a systematic effort made to collect information on key variable such as wage structure or quality of public sector management, let alone issues such as performance of government. However, these are the issues that the second-generation reforms will need to examine. In so doing, they will require a search for appropriate management skills.

\section{SKILL LOSS THROUGH HUMAN CAPITAL FLIGHT ${ }^{15}$}

The consequences of the "incomes policy" that the government is practising needs to be examined a little more carefully. As the real wage in the government sector declines, it sets up an adverse selection process by leading to an outflow of the relatively more capable/skilled (highly educated), and perhaps even more honest, people from the sector. Intuitively, it would seem that the wage rate in the private sector has to be equal to the wage rate in the public sector plus the expected return from corruption for the same level of human capital. Legitimate earnings may be preferred, however, to illegitimate earnings because of the social stigma, or the probability of detection and punishment attached to the latter. Thus, for the same level of human capital, a premium to compensate for these factors would be necessary. Even if expected earnings are equalised across the sectors, the private sector would be preferred at each level of human capital.

The possibility of adverse selection into government is quite possible when a declining real wage policy is followed in that sector. This would reinforce the stagflationary trends discussed above. There are many reasons why, in developing

\footnotetext{
${ }^{14}$ See Haque and Aziz (1998) Nunberg (1996) and Lienert and Modi (1997) for more details on the impact of the first generation of CSR.

${ }^{15}$ This issue received a fair amount of attention under the nomenclature of the "brain drain" in the seventies. At first, it was considered that since each individual obtains and consumes his marginal product, the emigration of the more skilled workers in response to economic incentives increases world income without reducing the welfare of those left behind. Additionally, remittances could improve welfare of those left behind. Bhagwati, pointed out that the loss of the scarce skills could produce and externality and hence reduce growth. However, this was before the era of the endogenous growth models which now accept the externality of education.
} 
countries, human capital of a high calibre might flow out of the government sector not only to the private sector but also out of the country.

- First, it may be recognised that the high $q_{c}$ are perhaps more internationally mobile. One only has to look at the advertisements in the economist as well as the staffing of research and academic positions at many institutions in industrial countries to substantiate this.

- Second, in many developing countries, government intervention has stunted the growth of the private sector. Because of nationalisations, licensing, and credit rationing, many potential private sector activities may not have developed to absorb such people. This sector frequently may not have growth to the point where it can utilise the high level of human capital that may be seeking alternatives to government because of this process.

- Third, government intervention may not allow adequately competitive compensation to these individuals. Direct incomes policies or extremely high rates of taxation are examples of such interventions. ${ }^{16}$

- Fourth, the provision of the infrastructural or public good may be important elements in terms of providing quality of life to people. As the efficiency of the government declines, difficulties such as deteriorating law and order, impose an additional tax burden. In such situations those with mobility have an additional incentive to move.

- Fifth, the nature of the production process may be such that high $q$ individuals may need to work in special environments that require large number of such individuals to be together or require specific forms of capital to combine with. This is the case of specialised research skills such as genetics and artificial intelligence research that can only take place in advanced industrial country environments. This would imply that the production function changes with growth and capital accumulation to allow increased usage of high quality individuals.

Basically these arguments suggest that the policy has an influence over the quality of talent that will be retained domestically. While public sectors have been oriented towards wage compression, and economies have been growing slowly, the

${ }^{16}$ Several multinationals have used these factors to advantage. They hire young individuals with good quality human capital from a developing country and use them at home in the early stages of their career where their level of compensation is in keeping with domestic market considerations. As these individuals outgrow that country, they move them into their multinational staff and pay them international salaries. Citibank is one of the companies that has used this very effectively. Such present value maximisation has also been used by governments where higher paying foreign postings have been used as an incentive to help boost the present value of individual earnings. Unfortunately, like most other areas of government activity, the effectiveness of such mechanisms has varied with the overall efficiency of the government as described above. 
optimal response of those that had skills, and were able to migrate, was to leave the country. We have a fair amount of anecdotal evidence on the subject of brain drain that suggests that there may be a talent pool that poor countries can draw from [see Table 3 and Haque and Aziz (1998)]. Given the relatively short supply of skills in these countries, even non-spectacular numbers appear to have consequences for institutional capacity.

\section{Table 3}

Estimates of Brain Drain from Selected Countries in Sub-Saharan Africa

\begin{tabular}{|c|c|}
\hline Country & Evidence \\
\hline Ghana & $\begin{array}{l}60 \text { percent of Ghanian doctors trained locally in the early 80s were } \\
\text { working abroad-creating critical manpower shortages in the } \\
\text { country's health service. Human Development Report (1992) }\end{array}$ \\
\hline Nigeria & $\begin{array}{l}\text { Nigeria experienced migration of highly skilled manpower. } \\
\text { Particularly hard hit medicine, universities, and airlines, 21,000 } \\
\text { Nigerian doctors overseas. World Bank (1990) Davies (1994) } \\
\text { Ricca (1989) }\end{array}$ \\
\hline Sudan & $\begin{array}{l}\text { In } 1978 \text { alone, } 17 \text { percent } f \text { Sudanese doctors and dentists, } 20 \\
\text { percent of university lecturers, } 30 \text { percent of engineers and } 45 \\
\text { percent of surveyors went abroad. By } 19852 / 3 \text { of Sudan's } \\
\text { professionals and technical workers had left the country. ILO } \\
\text { (1985) }\end{array}$ \\
\hline Zimbabwe & $\begin{array}{l}\text { Produces } 60 \text { doctors a year-has lost almost } 90 \text { percent of these } \\
\text { doctors to foreign countries. } \\
\text { Davies (1994) }\end{array}$ \\
\hline Zambia & $\begin{array}{l}\text { Ministry of health has a shortage of doctors estimated at } 549 \\
\text { doctors. } \\
\text { Chiposa (1988) }\end{array}$ \\
\hline
\end{tabular}

Brain drain may be defined as the international transfer of resources in the form of human capital that is not recorded in the BOP. ${ }^{17}$ Whereas measures of migration do not in any way distinguish between individuals, the concept of brain drain relates to the loss of skills or human capital to society or to the country from which migration takes place. It is meaningful only in an environment of scarce skills and relates only to those professional skills that require considerable investment and, therefore not easy to

\footnotetext{
${ }^{17}$ The analogy with capital flight is made in Haque and Kim (1995). Perhaps because of its ease of measurement, the flight of financial capital has received more attention, though in may countries anecdotal evidence suggests that human capital may also be a major impediment to progress.
} 
replace. Typically, the term is used to describe the loss of professional and technical skills such as scientists, academics, doctors, engineers and others with university training.

Emigration of professional skills occurs for three broad reasons.

- First among these is the incentive of a higher rate of return, often at a lower risk, to human capital in the host country. The host countries are often able to offer market-determined salaries at lower taxes, unlike the countries of origin where public sector dominates the professions and has an ethos of noncompetitive wages. Furthermore, the host countries have a stable macroeconomic and socio-political environment that provides security as well as substantial creature comforts, both of which often are in question in the home country.

- Second, for professional survival and growth, it might be important to be in the professional centres that are mainly in the advanced industrial countries. Without participation in such centres, the risk of professional marginalisation and obsolescence is great.

- Third, and related to the second is that poor countries, because of resource shortages or mismanagements, are frequently unable to provide complementary inputs for the practice of the concerned profession. For example, research scientists in universities may not have laboratory facilities, doctors may not have hospital equipment, etc. [See Danso (1995) and Davies (1994)].

Without going into further technical detail (for which the reader is referred to Haque and Kim (1995) Haque and Aziz (1998), the following results emerge.

Proposition 3. In a two-country world, where both countries are identical except in the level of production of $\mathrm{G}$, there exists a cut-off point $A^{M}$ in the ability distribution of the country with the lower level of $\mathrm{G}$, such that all agents from this country whose ability levels are higher than $A^{M}$ migrate to the country with higher G. Agents with ability less than $A^{M}$ remain.

Haque and Kim (1995) and Haque and Aziz (1998) show that there is an output and income loss with the migration of skills. Moreover, in both cases, the result of this migration is that the highest skill level in Ruralia, the poor country, is now $\mathrm{A}_{\mathrm{M}}<\mathrm{a}$ where a is the highest point in the ability distribution. Since growth is dependent on the highest ability level in the country, it would be reduced as a result of migration. Growth 
now is $\left(A_{M}-1\right)$ which is less than $(a-l)$, the rate that prevails in The richer country and that prevailed before migration. Output and per capita income too are lower. The loss of skills is a loss to the poorer country in terms of permanent reduction in incomes, as well as in the growth of output of the economy.

Proposition 4. Migration of skills can result in permanently lower output, profits and income levels in the poor country. Additionally growth may also be slowed down permanently relative to the richer country.

Brain drain, or human capital flight, has been dismissed as the manifestation of mere nationalism and indeed some nationalistic leaders have even used the brain drain rhetoric to argue for control on migration or demand payments for the migration. ${ }^{18}$ The former group argues that the brain drain reflects the need in international markets for specialised human capital: human capital tends to move to regions and occupations where its productivity is high. Nationalists regard a minimum level of professional skills as required for the functioning of the nation state and hold that these skills are the property of the nation state. The debate is then often obscured by into the age-old question of "should governments curb individual freedom of movement?"

As a result, the profession and development agencies have been somewhat ambivalent on this subject. At an aggregate level, human capital has been shown to be theoretically and empirically the more important variables for determining economic growth, with upper levels of education being strongly correlated with growth. Barro (1997) shows that upper levels of male education are strongly correlated with growth, with an extra year adding 1.2 percent to growth, while primary education is often significant and of the wrong sign. This is with the education variable being merely years of school attendance, without taking into consideration quality, certification and professional or technical attainment. Perhaps it is this inability to measure the scarce professional skills that is the concern of the subject of 'brain drain', that the subject has not received adequate attention. Despite numerous consultant and technical assistance reports for capacity building and civil service reform citing the lack of scarce skills as an important constraint to development, to date no systematic attempts at developing an assessment of needed skills in the poor countries has been undertaken. ${ }^{19}$

The causes of brain drain and the measures required to stem it are often confused primarily because both proponents and opponents become preoccupied with the curbs on migration. The analogy with capital is perhaps appropriate here. Just as capital literature.

${ }^{18}$ See Haque and Kim (1995) and Danso (1995) for a fuller discussion of some aspects of this

${ }^{19}$ Considerable sums are being spent to collect data on corruption, political and institutional arrangements, living standards etc. but hardly any on the assessment of whether universities have teachers of adequate quality. Such assessment may be important if domestic institution-building is a concern given that ghost workers and unqualified appointments in professional positions can create the impression of adequate staffing. 
controls are considered as undesirable for the prevention of capital flight, it should be taken as given that curbs on migration, no matter how cleverly designed, are an inappropriate response. The prescriptions for retaining domestic human capital are also similar to those normally suggested for attracting and retaining foreign investment: policies that foster market determined domestic returns to factors of production as well as friendly and stable socio-political environments.

The design of an appropriate policy response must recognise the need for the retention of the professional human capital must first be fully established. It is immediately obvious to those involved in technical assistance and training, that for the maintenance of systems for supervision and regulation, provision of social development (including health and education), development and maintenance of infrastructure and governance in general, key skills such as academic, accounting, engineering, managerial, and medical are required at various levels of quality. At a more general level, the continuous loss of the educated will retard the modernisation process as well as the development of domestic policy formulation. Brain drain can also reinforce the limited ability to generate needed skills in poorer countries. As the Human Development Report (1992) notes, “emigration also reduces Africa's capacity to train a new generation of professionals." 20

\section{CAN TECHNICAL ASSISTANCE REPLACE LOST SKILLS?}

A standard approach to dealing with the issue of loss, or lack of, scarce skills is the provision of technical assistance. International agencies and bilateral donors such as United States Agency for International Development use this approach extensively. Skills that are scarce in a developing economy provided by short-term, expatriate advisers, typically, at compensation levels higher those prevailing in international markets. ${ }^{21}$ This is to compensate for undertaking the hardship of moving from metropolitan centres. The high cost of the technical assistance is justified since it is expected that institutional development will be encouraged as the human capital input of technical assistance can galvanise a modern system in a short span of time. Once the system has been set in motion, the local human capital can maintain it at the low salary structure prevalent domestically.

There is no theoretical study of this model of technical assistance even though the amount of money allocated to such assistance is not trivial. To place things in perspective, Figure 3 presents data of technical assistance flows as a percentage of some

\footnotetext{
${ }^{20}$ Surprisingly, little has been done to evaluate and understand the problem. The International Organisation for Migration has had since 1983 a programme for "Return and Reintegration of Qualified African Nationals.” Since the beginning of the programme about 1200 nationals have been assisted in returning to 6 targeted countries. The IOM is targeting another 1000 by the end of 1998 [Davies (1994)].

${ }^{21}$ Typically, technical assistance is made available in areas of public sector responsibility such as institutional weaknesses. In such areas, the public sector rigidly maintains an uncompetitive wage structure [see Haque and Sahay (1995) and Haque and Kim (1995)]. Frequently, policy intervention of donors, especially for short term stabilisation, results in a reduction of public sector wages [See Kraay and Van Rijckeghem (1995)].
} 
Figure 3

Fig. 3. Technical Assistance Flows.

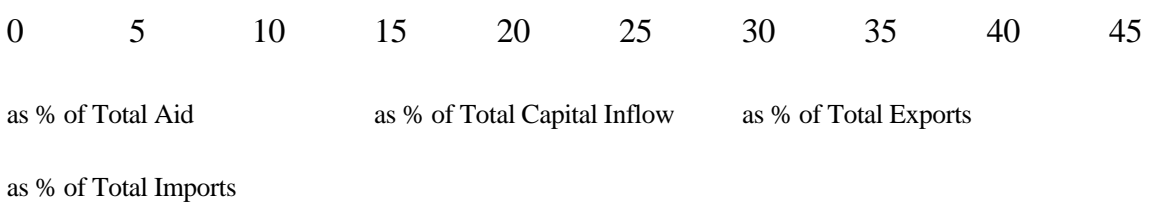

Africa

$\square$ Asia

Western Hemisphere

Transition

key economic variables. ${ }^{22}$ In Sub-Saharan Africa, it has averaged annually about 35 percent of total aid and about 32 percent of the total exports for the period 1991-95 (see Figure 3). Even for Asia where aid and technical assistance have been operating for a long time, it constitutes a substantial part of total aid.

Most countries that utilise technical assistance experience a substantial amount of brain drain. The anomaly of talent outflow from Africa and the inflow of technical assistance advisors to replace the talent has also been noted by analysts. Danso (1995) notes that "ironically there are 100,000 expatriates at work in Africa. Technical assistance in Sub-Saharan Africa increased by 50 percent between 1984 and 1987 and current estimates put the total cost at $\$ 4$ billion annually", a number confirmed by the World Bank. While Pakistan imports expensive foreign consultants, its skilled manpower is being very effectively used in very senior positions by major institutions such as Citibank, Advanced Micro Devices, Upjohn, the World Bank, etc.

For equity and other considerations, the technical assistance model prevents the migrants from a country to return as part of technical assistance. ${ }^{23}$ Any person who has

${ }^{22}$ According to the World Debt Tables of the World Bank, "grants" are defined as legally binding commitments that obligate a specific value of funds available for disbursement for which there is no repayment requirements. "Technical cooperation grants" include free-standing technical cooperation grants which are intended to finance the transfer of technical and managerial skills or of technology for the purpose of building up general national capacity without reference to any specific investment projects; and investment-related technical cooperation grants, which are provided to strengthen the capacity to execute specific investment projects.

${ }^{23}$ The $T A$ approach, therefore always places foreign experts in a country. By design, therefore, these experts have to spend the initial period of their stay in a country settling in and learning about the country. 
been a part of the brain drain can only return home at the low domestic salary and not at the technical assistance level of emoluments. The UN has actually mandated a salary structure in their offices that are situated in developing countries. The highest salary attainable by a resident in this salary structure is presented in Table 4 as a percentage of the midpoint of the entry level salary for an economist at the World Bank headquarters. Bear in mind that the UN local office jobs in many of these countries are among the more coveted. The structure of the professional policy-making/social science labour market in as follows: the lowest paid jobs are in the public sector; locally the UN jobs are preferred; and should the person be willing to move, headquarters jobs are desirable. It is not surprising then that the public sector lacks skills. What is surprising is that the question of the costs and benefits of the alternative channels of brain drain repatriation and technical assistance for institutional development in developing countries, which should be of obvious interest, are seldom studied.

Proposition 5. If migration is costly, then it is cheaper to retain any skill type than import it from a higher income country.

Suppose, as is usually the case, that skilled workers have already migrated. In this case, the comparison needs to be made between attracting an expatriate and a resident of the higher income country. To consider this aspect of technical assistance, we use the approach of Haque and Khan (1997) and assume that there is some discount factor $k<1$, such that the migrant from the poor country, if paid $k w$, would be indifferent to working in rich country for wage $w$ or returning home. Analogously we assume that there is a factor $m>1$ such that a resident of the rich country if paid $m w$, would be indifferent to working in either of the two countries. ${ }^{24}$ Now for a given wage $w^{T A}$, a higher skill level will obtain if poor country workers are encouraged to return than if the technical assistance programme relies only on rich country workers. If the technical assistance programme relies only on skills from the rich country, the highest skill level that returns will be $A^{u}$, while if migrants from poor countries are also included $A^{R}<A^{u}$ will also be induced to participate. The wedge ( $\left.m-k\right)$ which arises from different preferences of the concerned individuals for living in Ruralia results in these differing levels of talent supply. ${ }^{25}$

Proposition 6. For the same compensation, technical assistance programmes will attract higher skilled migrants than residents of a higher income country.

${ }^{24}$ The value of $m$, can be justified on grounds of hardship and moving to a new environment. It is empirically verifiable given the relatively generous expatriate packages that are given to those participating in the programmes.

${ }^{25}$ The result is fairly robust across different wage/ability profiles. See Haque and Khan (1997) for a further discussion. 
Table 4

Recommended Highest Salary Payable to Nationals as Percent of Entry Level World Bank Salary (mid point WB22)

\begin{tabular}{|c|c|c|}
\hline Country & Year & Percent \\
\hline \multicolumn{3}{|l|}{ Low Income Countries } \\
\hline Burkina Faso & 1995 & 35 \\
\hline Burundi & 1996 & 30 \\
\hline Central African Republic & 1990 & 75 \\
\hline Chad & 1996 & 52 \\
\hline Ethiopia & 1996 & 29 \\
\hline Ghana & 1996 & 37 \\
\hline Haiti & 1995 & 56 \\
\hline India & 1996 & 60 \\
\hline Kenya & 1995 & 61 \\
\hline Madagascar & 1995 & 16 \\
\hline Malawi & 1996 & 48 \\
\hline Niger & 1995 & 47 \\
\hline Pakistan & 1996 & 74 \\
\hline Rwanda & 1995 & 38 \\
\hline Zambia & 1996 & 52 \\
\hline Zimbabwe & 1996 & 48 \\
\hline \multicolumn{3}{|l|}{ Countries in Transition } \\
\hline Armenia & 1996 & 17 \\
\hline Belarus & 1996 & 19 \\
\hline Bosnia & 1995 & 29 \\
\hline Bulgaria & 1996 & 21 \\
\hline Czech Republic & 1996 & 47 \\
\hline Estonia & 1996 & 29 \\
\hline Hungary & 1996 & 29 \\
\hline Kyrgyz Republic & 1995 & 14 \\
\hline Latvia & 1996 & 40 \\
\hline Lithuania & 1996 & 24 \\
\hline Macedonia & 1995 & 42 \\
\hline Moldova & 1995 & 17 \\
\hline Poland & 1996 & 34 \\
\hline Romania & 1995 & 26 \\
\hline Russia & 1996 & 72 \\
\hline Ukraine & 1996 & 32 \\
\hline \multicolumn{3}{|l|}{ Other Countries } \\
\hline Bolivia & 1996 & 99 \\
\hline Brazil & 1996 & 158 \\
\hline Ecuador & 1996 & 11 \\
\hline Honduras & 1995 & 56 \\
\hline Indonesia & 1995 & 96 \\
\hline Israel & 1995 & 52 \\
\hline Jamaica & 1996 & 81 \\
\hline Mexico & 1995 & 139 \\
\hline Morocco & 1996 & 97 \\
\hline Nigeria & 1995 & 135 \\
\hline Peru & 1996 & 135 \\
\hline Philippines & 1995 & 80 \\
\hline Saudi Arabia & 1995 & 124 \\
\hline South Africa & 1996 & 80 \\
\hline Turkey & 1996 & 123 \\
\hline Venezuela & 1996 & 68 \\
\hline
\end{tabular}


Surprisingly, current technical assistance arrangements prohibit the inclusion of Ruralian citizens. It is widely believed, even by the UN, that the difference of $m$ and $k$ $(m-k)$, is very large (often a number approaching double digits in percentage terms). Given the human capital flight accumulations from poor countries and the limited skill agglomeration in them, this differential is clearly unrealistic.

Technical assistance is generally considered to be successful in solving shortterm physical implementation and technical problems. "The resulting over-reliance on substitute technical assistance (long-term expatriate advisors) was rather ineffective in building long-lasting and self-sustaining institutional capacity”. ${ }^{26}$ Dia (1995) and Ake (1996) appropriately point to the major cause of this failure: that such civil service reform programmes do not take into account the macro institutional/governance environment and its impact on civil service efficiency. The additional point that this paper makes is that such efforts are quite divorced from the need to develop the necessary talent and leadership in the civil service reform programme.

Technical assistance cannot be a substitute for the approach being proposed here-a comprehensive reform of the civil service that fully utilises domestic talent. A pricemeal approach to reform based on technical assistance can, in certain cases, lead to unbalanced development and less than durable solutions. For example, the "enclave" approach has been used for quick results. ${ }^{27}$ These take the form of donor-financed projects, management contracts with expatriate experts (e.g. DGTEX in Cote d'lvoire, French management of Air Afrique), or the separation and sometimes control of certain key government economic/financial functions by bilateral donors in exchange for their assistance (e.g. customs). Enclave entities are basically donor-driven, donor-dependent and unsustainable and often not in keeping with the drive for improved governance and better public expenditure management [Premchand (1996)]. They often result in dyarchical systems of accounting and governance that may not lend themselves well to control and management. ${ }^{28}$

\section{ISSUES IN PUBLIC SECTOR REFORM}

Much can be learnt from the civil service reforms that have been implemented in the industrial countries. The well-known reform episodes that are widely quoted are New Zealand, UK and USA, all of which were domestically designed and implemented by local talent. Yet there are several common themes that emerge from them. The

\footnotetext{
${ }^{26} \operatorname{Dia}(1995)$.

${ }^{27}$ Revenue generation is often considered an "enclave". The generation of additional revenues without first addressing the weaknesses in expenditures, could easily lead to a further waste of resources.

${ }^{28}$ Nunberg and Nellis (1995) note that interim solutions to pay and employment problems through specialised incentive schemes for topping up executive-level salaries for key government posts, or, more broadly, by widely supplementing civil service salaries through donor-financed activities are not enduring answers to the fundamental problems of civil service incentives; "indeed, they ultimately undermine the likelihood of devising a durable solution”.
} 
Thatcher reforms in the UK (see Box 1), and public sector reform in the New Zealand are well known in this regard. More recently, the "Reinventing Government" movement in the US has been blessed by the Clinton administration. All these efforts have been made to enhance the productivity of government. This is done in several ways: through the re-orientation of the role of government to core governance areas, through improvements in systems of work and operations, and through inducing quality human

\section{Box 1}

\section{Performance-based Civil Service in the UK}

Margaret Thatcher's Government adopted the following principles for running the British government in 1988:

(a) Separation of service delivery and regulatory functions into discrete chunks, each one called an Executive Agency.

(b) Agencies to have control over their budgets, personnel systems and management practices.

(c) Agency chief executive to be paid adequately to attract talent needed. Performance bonuses of up to 20 percent of their salaries could be paid but they must be forced to reapply for their jobs every three years.

(d) Agency CEOs to negotiate a three-year performance contract with their department, specifying the results they would achieve and the management freedoms they would be given.

(e) Setting of annual performance targets for each agency.

(f) All agencies on trial for their lives every five years.

\section{Results}

(a) 126 Executive Agencies, which employ almost 75 percent of all civil servants;

(b) CEOs now have the freedom they need to manage effectively; but both their pay and job security depend on their agency's performance against quantifiable standards.

(c) If his agency does not perform, it may be abolished, privatised or restructured at its five-year review.

(d) Overall, the British have shrunk their civil service by 15 percent and performance has steadily improved. Operating efficiency has increased by at least 2 percent a year. On average, agencies got by on 4.7 percent less operating money in 1994-95 than they had the year before. 
capital into government. The basic principles of reform can be summarised as follows: ${ }^{29}$

- Non-uniform, Open and Meritocractic Organisational Structures: No longer is the entire civil service straight-jacketed into one uniform grading system that seeks to put educators, policemen, jurists etc. on the same scale. Nor is only length of tenure rewarded. Instead the level of skill is contracted on terms related to its market opportunity cost. Selection is based on open competition and not only from the insiders and the insiders too are encouraged to be mobile.

- Incentive Based Systems to Attract Need Technical and Professional Skills: Public sector management requires technical skills and these skills can only be obtained through contracting with incentives for performance. The incentives could range from monetary compensation to recognition and honour. A high level position in the US public sector, for example, is considered valuable by the private sector and can be cashed in later. Consequently, these positions can be allocated at lower than market levels for the profile and expected compensation in the future. ${ }^{30}$

- Autonomous Professionally Run Institutions: Autonomous institutions that are controlled by governing bodies that are selected from the community where the executives are distanced from party politics under terms contracted with the elected government have been found to be efficient and well run. For example, central banks, educational institutions, hospitals, and regulatory commissions are all run in this manner in industrial countries. Efforts are made to find the best professionals to run these places. In order to do so they are given security of tenure and a clear goals for the duration of there tenure (see Box 2 for an interesting application of some of these principles to Pakistan).

- Decentralised Community-based Structures: For the provision of social services such as education, health and sanitation, decentralised structures firmly in the hands of the community are necessary. The ministries for these areas merely monitor and set guidelines and goals but do not get involved in actually running these establishments.

- Performance Based Organisations and Contracts for Managing the Public Sector: While in some countries the monitoring of budgetary allocations and the inputs of the public sector still remains of interest and auditing procedures

${ }^{29}$ While Reinventing Government remains the most important approach to developing principles for the reform of government, I am highlighting the principles that I feel might be important to understanding reform in Pakistan.

${ }^{30}$ It has long been known that veteran status from the army commands a premium in the market. 
Box 2

'Decentralise, Professionalise and Autonomise'

\section{Decentralisation}

Reduce the powers of the federal and provincial government and allow communities, towns cities and local governments to take over many of functions that are important to the community. Thus police, schooling health, parks and recreation can all be given to the local government. Two important outcomes of this should be noted. First, that the power of Islamabad has to be reduced and that duplication should be avoided. Decision-making as well as the utilisation of funds should devolve to the level required for the delivery of maximum benefit to the community. Secondly, both the federal government and the local and provincial government should be competing for resources especially the scarcest of all our resources - human and managerial. Consequently, the current civil service arrangement based on a centralised Public Service Commission, with an established hierarchy of service with federal service at the apex and the local at the lowest level would be inimical to the spirit of decentralisation.

\section{Professionalisation}

Our key ministries and institutions are managed according to an approach that was established in the last century. Even the English who designed that system have given it up. This system selects competent generalists early in life and offers them little additional training or incentive to professionalise and guarantees them key positions. Nowadays, in more advanced countries, the trend is for professional management in a highly competitive environment in both private and public management. Increasingly, governments are placing performance-based institutions on the basis of clearly written performance-based contracts in the hands of the finest professionals. Our system of a core civil service that has the protected right to all senior appointment regardless of professional capability is certainly not consistent with this. We have also seen the adverse effects of such a system and hence should be more than ready to reform along the lines of professionalisation.

\section{Autonmising}

Another modern trend that we see in all industrial countries is that of autonomous institutions. Apart from line ministries, most institutions such as universities, research institutions, school systems, regulatory bodies, tend to be autonomous agencies. At times governments can make key appointments, such as heads of agencies. Quite often, even these appointments are in the hands of independent boards of directors. For example, the government may be able to nominate a governor of a central bank but in most cases it cannot appoint a university president. Even where the government can appoint an agency head, tenure rules will prevent a capricious firing but hold the agency head to a clearly defined output goals. Hiring and wage and incentives structures within these institutions are not centrally controlled and subjected national uniformity standards, but remain an instrument of internal management control. 
are put in place for such accounting, in the advanced countries, performance auditing is practised. Performance indicators are determined and monitored and the contracts of individuals and public sector agencies are based on these indicators. The security of tenure of the chief executive and his team as well as the life of the agency can then be reviewed in the light of the performance on the PIs (see Box 1 for the Thatcher reforms and the use of the PIs).

- Open Transparent Systems: A. K. Sen pointed out that there can be no famine in an open society. The principle applies to good administration. Open and transparent governments are found to perform well. Because they are willing to reveal all and live under the scrutiny of the people, they are more likely to try to be careful about providing good governance. In turn, such a government is trusted by all.

All these areas of reform are very important to the improvement of public sector productivity, and should be a part of the comprehensive reform in low income countries. However, we have focused here on the human capital in the production of governance good for two reasons. First, a review of the evidence on the utilisation of human capital in government in the poor countries issue suggests why this may be a critical first step in the direction of public sector reform. ${ }^{31}$ Second, the improvement of systems within government, such as the setting up of performance-based organisations, will also require skills and talent.

\section{CONCLUSION}

Management of the public sector which is a key element of economic activity is too important an element to be left uninvestigated. To begin with the role of the government must be carefully defined to ensure that the public sector does not acquire an over-reaching position of market dominance which stifles private sector activity. In that context, the more innovative approaches to the provision of public sector good as well as public sector management need to be brought into the mainstream of economic analysis and policy. ${ }^{32}$

Human resource policy in the government should be such that the best people are drawn into government. While the education policy should be seeking to develop the quality of education at all levels, given the importance of public sector output, every effort should be made to place, and retain, the best available human capital into the government.

This would involve not only the maintenance of a wage policy that makes the public sector competitive but also the elimination of other practices that restrict the

\footnotetext{
${ }^{31}$ Some of this evidence is presented in Section III below.

${ }^{32}$ Reinventing government.
} 


\section{Box 3}

The Principles of Reinventing Government

\section{Catalytic Government: Steering Rather than Rowing}

Catalytic governments separate "steering" (policy and regulatory) functions from "rowing" (service-delivery and compliance functions).

Community-Owned Government: Empowering Rather than Serving

Community-owned governments push control of services out of the bureaucracy, into the community.

Competitive Government: Injecting Competition into Service Delivery

Competitive governments require service deliverers to compete for their business, based on their performance and price.

\section{Mission-Driven Government: Transforming Rule-Driven Organisation}

Mission-driven governments deregulate internally, eliminating many of their internal rules and radically simplifying their administrative systems, such as budget, personnel, and procurement.

\section{Results-Oriented Government: Funding Outcomes, Not Inputs}

Results-oriented governments shift accountability from inputs ("Did you follow the rules and spend according to the appropriated line items?”) to outcomes, or results.

\section{Customer-Driven Government: Meeting the Needs of the Customer, Not the Bureaucracy}

Customer-driven governments treat those they serve-the parents whose children they teach, the people who line up to renew driver's licenses, or the general public-as their customers.

Enterprising Government: Earning Rather than Spending

Enterprising governments focus their energies not only on spending money, but on earning it.

\section{Anticipatory Government: Prevention Rather than Cure}

Anticipatory governments seek to prevent problems rather than delivering services to correct them.

Decentralised Government: From Hierarchy to Participation and Teamwork

Decentralised governments push authority down through the organisation or system, encouraging those who deal directly with customers to sake more of their own decisions.

Market-Oriented Government: Leveraging Change Through the Market

Market-oriented governments often restructure private markets to solve problems rather than using administrative mechanisms such as service delivery or command-and-control regulation.

(From Reinventing Government.) 
efficient working of public sector wage policy. Common among these are the existence of large barriers to entry to the government; a policy of attempting to lock in widely differing career streams into uniform government grades and pay scales; and inadequate performance objectives and monitoring. ${ }^{33}$

For public sector performance that is supportive of private sector production, the institutional framework should be supportive of efficiency in government. Thus the ability of the government to self-police which is do critical to the success of its objectives has to be an important part of a package that is offered to the public servant.

The literature on reform and growth emphasises concepts of downsizing and reorienting the public sector as well as community participation and the development of civil society. ${ }^{34}$ The general view is that development of rules and institutions is enough for achieving the necessary governance and civil society objectives required for growth. The agents who will make this happen are often not taken into account. This paper argues that the allocation of talent especially its use in the public sector is likely to be important to the successful implementation of development plans. How the incentives are structured for the technocrats, the managers, and the professionals will determine the talent that offers itself to run key institutions and organisations, and could determine the efficiency of policy implementation and design. One explanation for the weak performance of the public sector in Pakistan may be the lack of attention to Pakistani talent in the design of reform. While many reforms were being planned and implemented badly, Pakistani talent, not being able to find a place at home, was migrating abroad. Many of the expatriate thinkers on reform were unable to see the implications of this, since in more developed economies skills are abundant. In Pakistan, the skill shortage has been significant, prompting donors to attempt to fill the ever-widening gaps through out-migration of skills through expatriate experts financed by technical assistance.

Civil service reforms have primarily been concerned with cost-cutting and containment. The issue of productivity and the need for appropriate human capital for it have largely been secondary. The paucity of human capital has been recognised, but only to talk about a slower pace of modernisation and an increased reliance on external technical assistance. The migration of skills and the possibility of correcting the prices such that domestic skills resident overseas may return is seldom considered seriously. However, it is asserted that the lack of domestic skills may not make it possible to operate a level of efficiency that is obtained in the advanced industrial countries. For example, the New Public Management approach which relies on autonomous performance-based agencies for the management of the public sector is considered to be inappropriate primarily because of the shortage of technical skills (see Box 1).

${ }^{33}$ Reinventing government.

${ }^{34}$ For more recent discussions of the importance of rules in the development process see Douglas C. North (1993) and Dhonte and Kapur (1996). 
Reform must therefore take into careful consideration the organisation of the public sector as well as the skill retention at home, aspects which were ignored in the past. It is only through such reform that the intermediate good of governance will be efficiently produced. And it is the governance good that has been increasingly found to be an important cornerstone of a country's institutional foundation. In developing the public sector, it is important to consider the human capital that the public sector is able to attract as that will determine the quality of its output. Consequently, as we have shown the next generation of civil service reform must bear in mind the incentives to human capital in the public sector. The structure of wages in the public sector is, therefore, an important policy tool for maintaining public sector efficiency.

The issue of public sector management and wage policy also has implications for the control of corruption. Many developing countries have found corruption to be an important impediment to the development process (see Mauro (1996). Haque and Sahay (1996) and Murphy, Schleifer and Vishny (1991) have shown that an appropriate response for dealing with corruption and rent seeking may be the retention of appropriate incentives for skills and honest productive behaviour in the public sectors in developing countries.

Domestic professions and the technical skills have proven to be extremely necessary to the development of civil society and better public administrations here in the U.S. Not only is the agglomeration of such skills important for the design of policy and reform, but also necessary for analyses and critiques that help foster domestic debate and ownership of such reform. Without this dissemination and debate, which can only be done by domestic groups, it is hard to see the development of civil society. Moreover, authoritative patrimonial states will remain unchecked, except through the international agency of restraint whose interests may or may not converge with those of the people.

\section{REFERENCES}

Adamolekum, Lapido, de Lusignon Guy, and Atomate Armand (n.d.) Civil Service Reform in Francophone Africa. (World Bank Technical Paper 357.)

Alfiler, Ma. Concepcion P. (1986) The Process of Bureaucratic Corruption in Asia: Emerging Patterns. In Ledivina V. Carino (ed) Bureaucratic Corruption in Asia: Causes, Consequences and Controls. JMC Press Inc., Quezon City, Manila, Philippines.

Barro, Robert (1990) Government Spending in a Simple Model of Endogenous Growth. Journal of Policy Economy 98:5 S103-26.

Bhagwati, Jagdish N. (1982) Directly Unproductive, Profit-seeking (DUP) Activities. Journal of Political Economy 90:5.

Chaudhry, Shahid Amjad, Reid Gary James, and Malik Waleed Haider (eds) 
(1994) Civil Service Reform in Latin America and the Caribbean: Proceedings of a Conference. World Bank, Washington, D.C. (Technical Paper, No. 259.)

Collier (1996) The Role of State in Economic Development: Cross-Regional Experiences. Paper presented to AERC Plenary. December.

Danos, Kwaku (1995) The African Brain Drain: Causes and Policy Prescriptions. Scandinavian Journal of Development Alternatives (Sweden) 14: 249-64.

Davies, Desmond (1994) African Brain Drain. West Africa (U.K.), No.4066:143235, September.

Dia, Mamadou (1995) Africa's Management in the 1990s and Beyond: Reconciling Indigenous and Transplanted Institutions. Washington, D.C., World Bank.

El Minawwi, Alhmed (1995) Sudan's Brain Drain: Is this Country Losing Its Head(s)? Sudanow (Sudan) 19: 21-22, December.

Flanagan, Robert J. (1995) Wage Structures in the Transition of the Czech Economy. (International Monetary Fund Staff Papers, 42-4, 836-54.)

Haque, Nadeem Ul, and Jahangir Aziz (n.d.) The Quality of Governance: Second Generation. Civil Service Reform in Africa. IMF Working Paper Forthcoming Journal of African Economics.

Haque, Nadeem Ul, and Kim, Se-jik (1995) Human Capital Flight: Impact of Migration on Income and Growth. September. (IMF Staff Papers.)

Haque, Nadeem Ul, and M. Ali Khan (1997) Institutional Development: Skill Transference Through a Reversal of "Human Capital Flight”, or Technical Assistance. (IMF Working Paper WP/97/89.)

Haque, Nadeem Ul, and Ratna Sahay (1996) Do Government Wage Cuts Close Budget Deficits?-Costs of Corruption. December. (International Monetary Fund Staff Papers.)

Haque, Nadeem Ul, Peter J. Montiel, and Stephen Sheppard (1997) Public Sector Efficiency and Fiscal Austerity. November. (IMF Working Paper.)

Heller, Peter S., and Alan A. Tait (1984) Government Employment and Pay: Some International Comparisons. International Monetary Fund, Washington, D.C. (IMF Occasional Paper No.24.)

Hewitt, D., and C. Van Rijckeghem (1995) Wage Expenditures of Central Governments. Washington, D. C., International Monetary Fund. (IMF Working Paper.)

International Monetary Fund (1995) World Economic Outlook. Washington, D. C. April.

Kallen, Denis (1994) Brain Drain and Development: Opportunity or Threat? Higher Education Policy (U.K.) 7: 11-15, December.

Klitgaard, Robert (1989) Incentive Myopia. World Development 17:4 447-459. 
Klitgaard, Robert (1995) Adjusting to Reality: Beyond "State vs. Market”. In Economic Development. International Centre for Economic Growth, Press San Francisco, California.

Klitgaard, Robert (1995) Institutional Adjustment and Adjusting to Institutions. (World Bank Discussion Paper 303.)

Kraay, Aart, and Caroline Van Rijckeghem (1995) Employment and Wages in the Public Sector-A Cross-country Study. International Monetary Fund, Washington, D. C. (IMF Working Paper, WP/95/)

Krueger, Anne O. (1974) The Political Economy of the Rent-Seeking Society. American Economic Review 46:3.

Lienert, Ian, and Jitendra Modi (1997) A Decade of Reform in Sub-Saharan Africa. Draft, IMF, Washington, D.C.

Lindauer, David, and Barbara Nunberg (eds) (1994) Rehabilitating Government: Pay and Employment Reform in Africa. Washington: The World Bank.

Mauro, Paulo (1995) Corruption and Growth. Quarterly Journal of Economics 681-712.

Mookherjee, Dilip, and I. P. L. Png (1995) Corruptible Law Enforcers: How Should They Be Compensated? Economic Journal 105: January 145-159.

Peil, Margaret (1995) Ghanaians Abroad. African Affairs (U.K.). 94:345-67, July.

Premchand, A. (1996) Erosion of Expenditure Management Systems: An Unintended Consequence of Donor Approaches. WP/96/102, IMF, September.

Premchand, A. (1996) Issues and New Directions in Public Expenditure Management. November. (IMF Working Paper, WP/96/123.)

Rose-Ackerman (1975) The Economics of Corruption. Journal of Public Economics 4: 127-203.

Samad, Abdus (1993) Governance, Economic Policy and Reform in Pakistan. Lahore: Vanguard Books.

Shapiro, Carl, and Joseph E. Stiglitz (1984) Equilibrium Unemployment as a Worker Discipline Device. American Economic Review 74: 433-44, June.

Shleifer, Andrei and Robert W. Vishny (1993) Corruption. The Quarterly Journal of Economics 599-617, August.

Simanovsky, Stanislav, and Osteuropa Wirtschaft (Germany) (1994) Brain Drain from the Former Soviet Union and the Position of the International Community. 39: 17-25, March.

Southern African Economist (Zimbabwe) (1994) Long Way from Development. 7: 11, April.

Srinivasan, T. N. (1973) Tax Evasion: A Model. Journal of Public Economies 2:4 339-346.

Suwanwela, Charas (1994) Disciplinary Specialism in Highly Mobile Professionals. Higher Education Policy (U.K.) 7: 29-30, December. 
Tanzi, Vito (1994) Corruption, Government Activities, and Markets. International Monetary Fund, Washington, D. C. (IMF Working Paper No.WP/94/99.)

The Volker Commission (1990) Leadership for America: Rebuilding the Public Service. Massachusetts: Lexington Books, Lexington.

The World Bank (1992) Governance and Development. The World Bank, Washington D.C.

Van Ginneken, Wouter (ed) (1991) Government and Its Employees: Case Studies of Developing Countries. Brookfield, Vt.: Gower.

Virmani, Arvind (1987) Tax Evasion, corruption and Administration: Monitoring the People's Agents under Symmetric Dishonesty. The World Bank, Washington D.C. May. (DRD Discussion Paper, Report No.DRD271.)

Wade, Robert (1982) The System of Administration and Political Corruption: Canal Irrigation in South India. Journal of Development Studies 18:3 287-328. 